\title{
Population size estimation of Aeshna caerulea (Odonata: Aeshnidae) in the Czech part of Úpské rašeliniště bog (Giant Mountains)
}

\section{Aleš Dolný}

Population size estimation of Aeshna caerulea (Odonata: Aeshnidae) in the Czech part of Úpské rašeliniště bog (Giant Mountains). - Čas. Slez. Muz. Opava (A), 62: 83-89, 2013.

\begin{abstract}
Aeshna caerulea (Azure Hawker) is present as a post-glacial relict in central European mountains. This species is listed as critically endangered in the Czech Republic (very restricted distribution occurring in two isolated populations) and the European population trend of this species is decreasing. The main objective of the study was to estimate the population size of A. caerulea in the Úpa bog National Nature Reserve (Czech Republic) using capture-mark-recapture data. Population estimates of adults using the Schnabel method was 425 (the 95\% confidence limits: 248.1 / 992.3), and using the Schumacher-Eschmeyer method was 416 (the 95\% confidence limits: 326.8 / 570.4). Imago activity became apparent at the beginning of July. This study has suggested that the possible future threats for the A. caerulea in the Czech Republic are drying up, air nitrogen depositions, eutrophication, pollution of water by external sources, and terrestrification, mainly as a result of global warming.
\end{abstract}

Keywords: Dragonfly conservation, Aeshna caerulea, Odonata, Population estimates, Glacial relict, Peat-bog.

\section{Introduction}

Aeshna caerulea (Fig. 1,2) is a boreal species that is numerous in Eurasias polar regions, post-glacial relict in Scotland, central European mountains and the Caucasus. This species can be found in alpine and arctic moors, heaths and tundra. It breeds in bog pools and sedge swamps, and is seldom found below 1,000 $\mathrm{m}$ a.s.l. in the Alps (Clausnitzer 2009). For example, in the Swiss Alps, breeding of A. caerulea has been observed to breed between $1318 \mathrm{~m}$ and $2230 \mathrm{~m}$ a.s.l. The lower vertical distribution is probably confined by the mild climatic conditions and interspecific competition while the upper limit is mainly restricted by the lack of suitable breeding habitats with lush vegetation, organic matter and corresponding thermal conditions (Wildermuth 2012).

Within the Czech Republic this species, as a post-glacial relict, occurs only in two isolated populations colonizing the highest altitudes of the country - the mountain ranges Krkonoše Mts., and Šumava Mts. The species is stenotopic, inhabiting a specific biotope - lakes and pools by raised mountain bogs in montane and alpine zones. Imagoes prefer open, sunny areas with low Piunus mugo stands. In the Krkonoše Mts. it inhabits altitudes of 1190-1435 m a.s.l. and in the Šumava Mts. altitudes of 1025-1135 m a.s.l., however the largest known population is located in the Krkonoše Mts. - 1430 m (the Úpa Bog, Fig. 3-5) (Dolný et al. 2007, Holuša \& Vaněk 2008).

A. caerulea is widespread in the Eurasia's polar region, but became to locally scarce and declining in some areas of its range, particularly in central Europe, where it is listed in threat categories of regional red lists (Clausnitzer 2009). In the Czech Republic the species is critically endangered (Hanel, Dolný \& Zelený 2005). In the European red list, the population trend of this species is categorized as decreasing (Kalkman et al. 2010). This species became endangered mainly due to by habitat destruction (e.g. the clear-cutting of forests), grazing livestock that destroys the breeding habitats, changes in management regimes of nonagricultural based land and infrastructure development, especially tourism but recently also by climate change. Therefore, restoration and conservation of its habitat are required (Clausnitzer 2009, Wildermuth 2012). 
There are several conservation actions having regard to the protection of populations of Aeshna caerulea, including monitoring its population trends and range. The main objective of this research study is to estimate of size of the most important population of A. caerulea in the Czech Republic (using capture-mark-recapture data), including the description of the overall dragonfly assemblage in the researched locality. In general, these biomonitoring data can be used to identify priority locality for research and conservation, and to quantify the response of the population to disturbance and management interventions.

\section{Methods}

\section{Study area}

The study site is the Úpské rašeliniště peat bog with an area of 10 hectares, belonging to the Úpa bog National Nature Reserve located on both sides of the Czech-Polish border, located near the upper boundary of the Subalpine zone of Krkonoše Mts. (Giant Mountains) with mat-grass meadows, swiss mountain pine stands and nordic peat-bogs (ca. $5 \mathrm{~km}$ north-west of Pec pod Sněžkou, the north part of the Czech Republic; $50^{\circ} 44^{\prime} 4.547^{\prime \prime} \mathrm{N}, 15^{\circ} 42^{\prime} 25.091 " \mathrm{E}$; an average altitude of $1425 \mathrm{~m}$ a.s.l.). The vegetation consists of oligotrophic communities belonging to the Oxycocco-Sphagnetea, and of minerotrofic fen communities of the class Scheuchzerio-Caricetea fuscae, the dominant species of above-ground cover are Pinus mugo, Sphagnum sp., Eriophorum vaginatum, Scheuzeria palustris and Carex sp.

In the central part of the bog there are bog pools and swaps (Fig. 3-5). The biggest bog pool of the Czech part of Úpa bog covers an area of $1245 \mathrm{~m}^{2}$. The lake has a maximum depth of $1.05 \mathrm{~m}$, an average depth of 0.65 $\mathrm{m}$, a water volume of $790 \mathrm{~m}^{3}$, a shoreline length of $163 \mathrm{~m}$ (Fig. 4). The bog pools have waters of low $\mathrm{pH}$ (range of 4.05-4.7), middle dissolved oxygen concentration (range of 6.6-9.2 $\mathrm{mg} \cdot \mathrm{l}^{-1}$, the percent saturation of $60-90 \%$ ) and low conductivity (range of 7-12 $\mu \mathrm{S} / \mathrm{cm}$ ) (Pošta 2005).

\section{Odonate sampling}

The Capture mark-recapture method (CMR method) was used to discover the population size of A. caerulea. Adults of A. caerulea were marked during the whole time period of imago occurrence in 7 capture sessions (1.2.vii.2012, 5.vii.2012, 24.-27.vii.2012). Marking was carried during warm, bright or partially cloudy days $\left(\geq 25^{\circ}\right.$ C), always for 6 hours between 10 a.m. and 5 p.m. Marking was carried out on the entire area of a locality with the aim of capturing the greatest amount of specimens possible. Each individual was marked with unique mark on the wings using permanent marker (each individual had unique code). This avoids any confusion of individual specimens. Individuals recaptured in the day of marking were not taken into account. Within each (re-) capture of each individual several parameters were recorded: location, date, exact time and weather conditions at the time of capture.

Furthermore, abundances of other species of Odonata were estimated during the regular walks at monitored sites. Semi-quantitative estimates of abundance are based on the methodology the British Dragonfly Society (BDS 2012). The nomenclature of all taxa is following to Van Tol (2005).

\section{Data analysis - Mark-recapture method}

Data from CMR for population size estimates were analysed using the Schnabel and the SchumacherEschmeyer method (package FishR); extension of the Petersen estimator to a series of samples, based on the proportion of marked animals present in the sample (Krebs 1999). This method assumes that the populations are closed.

\section{Results}

\section{Population size estimates and flying season of Aeshna caerulea}

In 2012, we marked 83 specimens, 21 females and 62 males. Total number of recaptures over entire study was only 7. Population estimates using the Schnabel method of adults was 425, and population estimates using the Schumacher-Eschmeyer method was 416 (Tab. 1).

In 2012, imago activity became apparent at the beginning of July; the first immature imago was discovered on 1.vii.2012. The end of the adult activity came in the first ten days of August. 


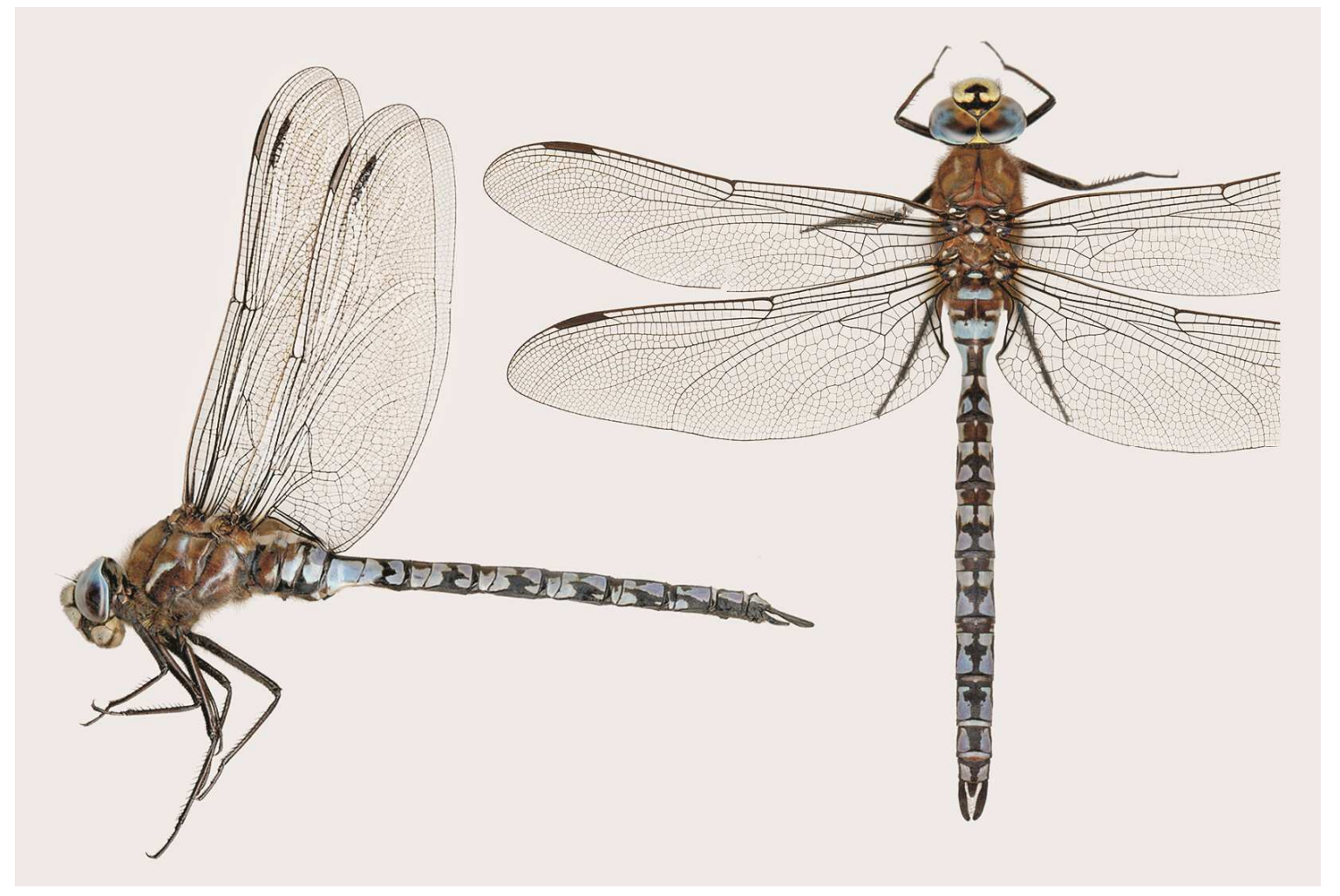

Fig 1: Male of Aeshna caerulea; it is one of the smaller species of family Aeshnidae. Males have bright azure blue spots on the abdominal segments and the thorax.

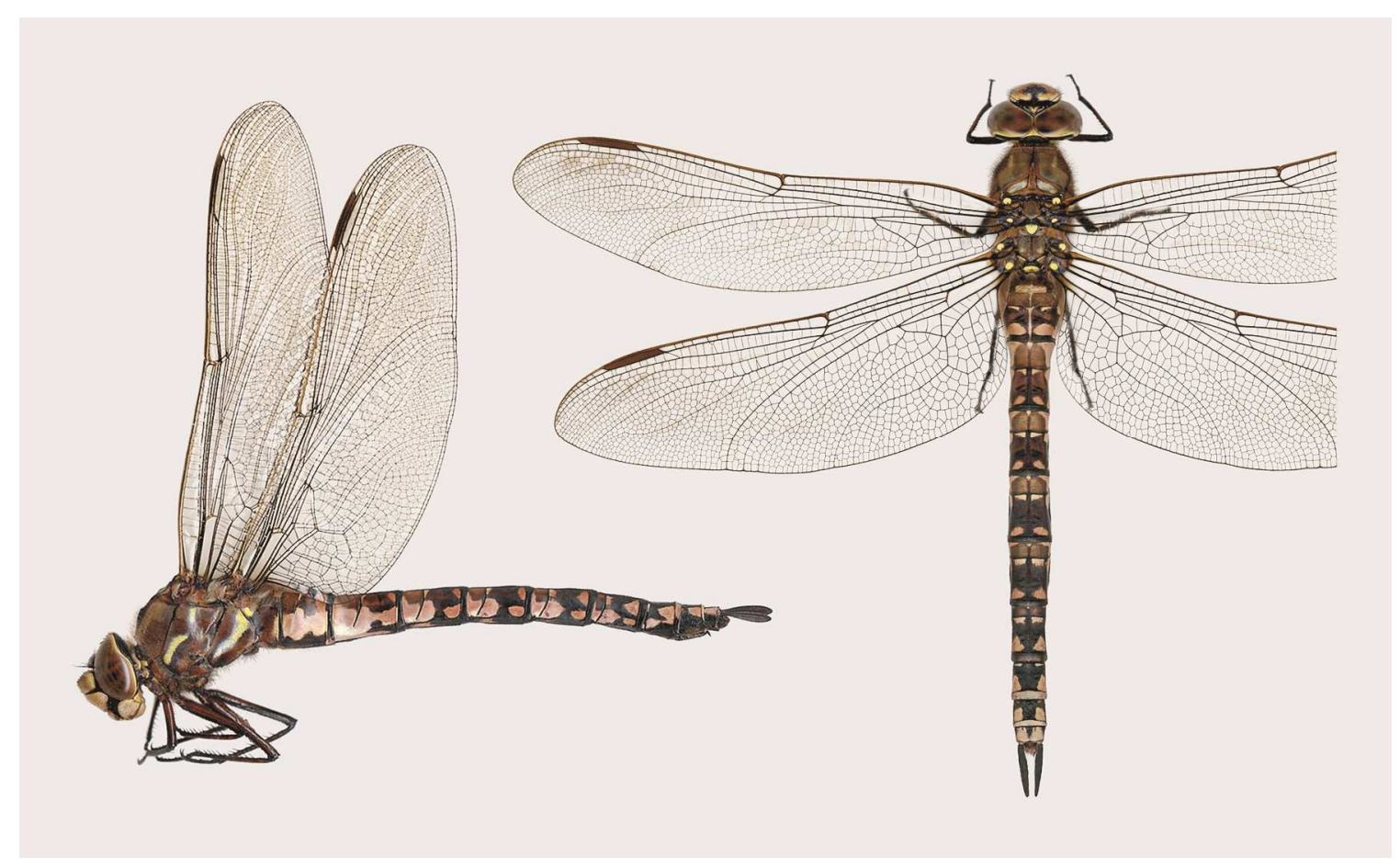

Fig 2: Female of Aeshna caerulea - a brown colour form. 
Tab 1: Schnabel and Schumacher-Eschmeyer population size estimates for Aeshna caerulea in 2012 at Úpa bog (using capture-mark-recapture method - CMR); $(\mathrm{N}=$ estimates of population abundance; invSE = the inverse standard errors, LCI = lower and UCI = upper confidence intervals).

\begin{tabular}{|l|c|c|c|c|}
\hline Method & N & invSE & LCI & UCI \\
\hline Schnabel & $\mathbf{4 2 5}$ & 0,000888 & 248,1 & 992,3 \\
\hline Schumacher-Eschmeyer & $\mathbf{4 1 6}$ & 0,000307 & 326,8 & 570,4 \\
\hline
\end{tabular}

\section{Overall dragonfly assemblage in the researched locality}

During this study, a total of 470 individuals from 8 species and belonging to 5 families were recorded at Úpa bog:

\section{Subordo: Zygoptera}

Family: Coenagrionidae

Coenagrion Kirby, 1890

Family: Lestidae Coenagrion puella (Linnaeus, 1758)

Lestes Leach, 1815

Lestes sponsa (Hansemann, 1823)

Subordo: Anisoptera

Family: Aeschnidae

Aeshna Fabricius, 1775

Aeshna caerulea (Ström, 1783)

Aeshna cyanea (O. F.Müller, 1764)

Family: Corduliidae

Aeshna juncea (Linné, 1758)

Somatochlora Sélys, 1871

Family: Libellulidae

Somatochlora alpestris (Sélys, 1840)

Sympetrum Newman, 1833

Sympetrum danae (Sulzer, 1776)

Leucorrhinia Brittinger, 1850

Leucorrhinia dubia (Vander Linden, 1825).

The most often observed species were Aeshna caerulea, A. juncea and Somatochlora alpestris. Often observed were Aeshna cyanea and Leucorrhinia dubia. Larvae and/or exuviae of 5 species were found. The records of Aeshna caerulea and Somatochlora alpestris are the most interesting from the faunistic, ecological and conservation point of view (Tab. 2).

Tab 2: Abundance, presence of development cycles, copulation and oviposition of Odonata species recorded in the investigated nature reserve in the year 2012.

Explanations: L - larvae; E - exuviae; J - immature adult; A - adults; K - copulation; O - oviposition; Ab abundance: 1 - 1 specimen, 2 - 2-5 specimens, 3-6-10 specimens, 4 - 11-20 specimens, 5-21-50 specimens, 6-50-100 specimens; RL - Red list of threatened species in the Czech Republic. Invertebrates: CR - Critically Endangered, E - Endangered, VU - Vulnerable.

\begin{tabular}{|c|c|c|c|c|c|c|c|c|}
\hline Druh & $\mathrm{L}$ & $\mathrm{E}$ & $\mathrm{J}$ & A & $\mathrm{K}$ & $\mathrm{O}$ & $\mathrm{Ab}$ & RL \\
\hline \multicolumn{9}{|l|}{ ZYGOPTERA } \\
\hline Coenagrion puella & & & & + & & & 2 & \\
\hline Lestes sponsa & & & & + & & & 2 & \\
\hline \multicolumn{9}{|l|}{ ANISOPTERA } \\
\hline Aeshna caerulea & & + & & + & + & + & 6 & $\mathrm{CR}$ \\
\hline Aeshna cyanea & + & & & + & & & 4 & \\
\hline Aeshna juncea & + & + & + & + & + & + & 6 & $\mathrm{VU}$ \\
\hline Somatochlora alpestris & & + & & + & + & + & 5 & EN \\
\hline Sympetrum danae & & & & + & & & 1 & \\
\hline Leucorrhinia dubia & + & + & + & + & + & + & 4 & $\mathrm{VU}$ \\
\hline
\end{tabular}






Fig 3: Aeshna caerulea breeds in bog pools and sedge swamps, prefers smaller and shallower pools with rich emergent vegetation, that would be seriously affected by climate change; the Úpa Bog (1430 m) in the Krkonoše Mts.

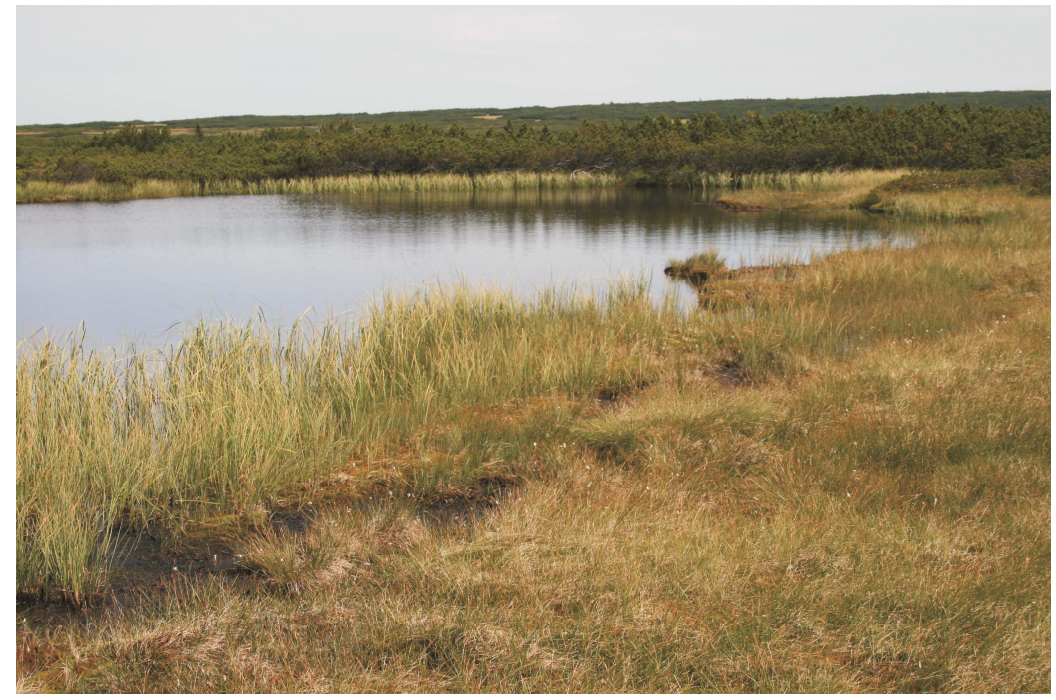

Fig 4: The biggest bog pool of the Czech part of Úpa bog covers an area of $1245 \mathrm{~m}^{2}$.

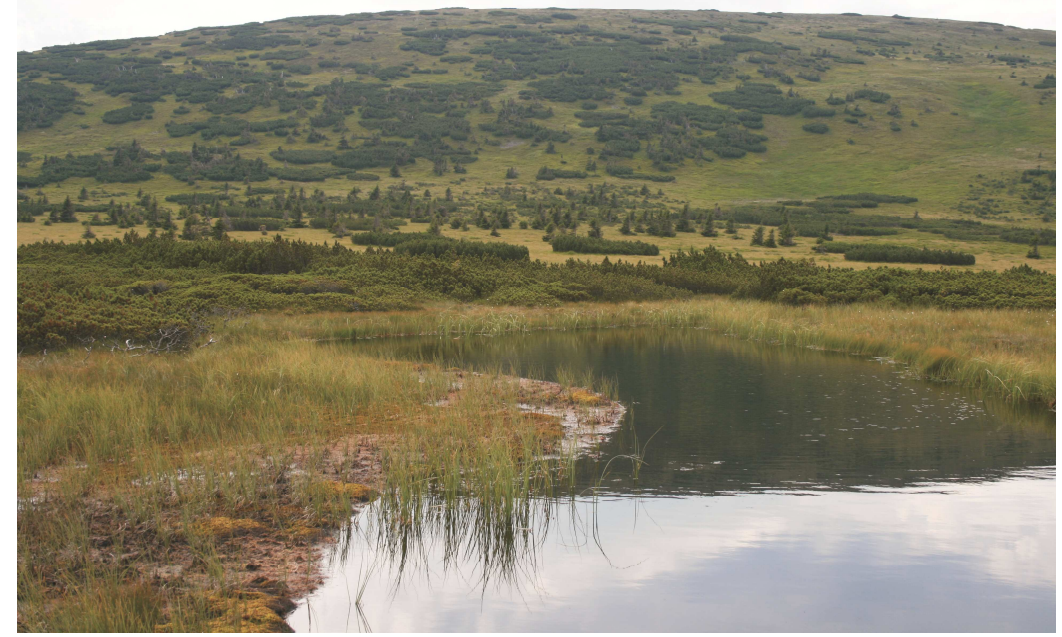

Fig 5: Strongest competition art to A. caerulea is A. juncea, commonly inhabits larger, deeper waters which often have less emergent vegetation. 


\section{Discussion}

Within the frame of European legislation (Natura 2000), dragonflies are the most prominent group of aquatic insects and generally of aquatic invertebrates. Following butterflies and beetles, dragonflies are in the terms of conservation in the territory of European Union the third most prominent order of insects, despite the relatively low (ca. 130 species) species richness (Cardoso 2012).

Seventy- three dragonflies and damselflies are known to occur in the Czech Republic, and only 6 of them are recognized as relict species. Five of these species (Nehalennia speciosa, Aeshna caerulea, A. subarctica, Somatochlora alpestris, S. arctica) are specialists of dystrophic habitats (peat bogs) whereas Sympecma paedisca occurs also in more nutrient-rich standing waters (Habel \& Assmann 2010). The montane environment is unambiguously preferred by two glacial relics, particularly Aeshna caerulea and Somatochlora alpestris, which also occur in the Úpa peat bog.

There are three main types of peatland occurring in the Czech Republic. At first, typical ombrogenous raised bogs. Secondly, mountain or sub-mountain transition mires and finally acid moss-rich fens. The bogs of the Czech Republic host altogether 51 dragonfly species, which is more than $70 \%$ of the species occurring in the country (Dolný et al. 2007). In these specific habitats live tyrphobiontic and tyrphophilous - the species typical for raised bog odontocenoses - but also eurytopic (generalists) dragonfly species. From the more than 50 dragonfly species of bogs in the Czech Republic only one half shows closer relation to the peat bogs in the Czech Republic. Only 5 species are really tyrphobiontic: Aeshna caerulea, A. subarctica, Somatochlora arctica, S. alpestris, Leucorrhinia dubia (Dolný et al. 2007, Dolný \& Bulánková 2004).

Although the habitat range of A. caerulea in Central Europe is restricted to the higher mountains, the species is not a typical psychrophile. Due to the brown colour of the water and the dark bottom ground, typical breeding sites of $A$. carulea, are warm habitats even in cold climates. Young larvae are thermophilic and need more or less constant temperatures of about $20^{\circ} \mathrm{C}$, while older larvae generally tolerate the lower temperatures but prefer also higher values. But the adult preference for lower temperatures restricts the distribution of $A$. caerulea to the cooler climates of the high North and subalpine and alpine zones (Sternberg 1997).

Typical co-occurring species of Aeshna caerulea are A. juncea, Somatochlora alpestris and Leucorrhinia dubia, and then follow A. cyanea, Coenagrion puella and S. arctica. This is also confirmed by this study, as shown in Tab. 2. Strongest competition species to A. caerulea is probably A. juncea. This species may benefit from larger body size and wider ecological range. While the species Aeshna caerulea prefers smaller and shallower pools (Fig. 3), A. juncea is widely adaptable, and commonly inhabits larger, deeper waters which often have less emergent vegetation (Fig. 4, 5), that would be less affected by climate change. So, this interspecific competition may pose a considerable threat to the populations of A. caerulea (Wildermuth 2012).

Some of the recent studies have revived the concept of the minimum viable population (MVP). MVP is the smallest possible size of the population of a species in the wild, such that it can survive without facing extinction from the natural stochasticity (Flather et al. 2011). Many studies conclude that long-term persistence requires $\geq 5000$ adult individuals respectively the MVP for most species will exceed a few thousand individuals (Traill et al. 2007). But MVP is unaffected by taxonomy, life history or environmental conditions. Flather et al. (2011) find that neither data nor theory supports its general applicability, raising questions about the utility of MVP for conservation planning.

This study has suggested that the possible future threats for the A. caerulea in the Czech Republic are drying up, air nitrogen depositions, eutrophication, pollution of water by external sources, and terrestrification processes, mainly as a result of global warming. 
Acknowledgements: This paper was written in connection with an Institute of Environmental Technologies project, reg. no. CZ.1.05/2.1.00/03.0100, supported by the Research and Development for Innovations Operational Programme financed by the Structural Funds of the Europe Union. I would like to thank Kateřina Dolná for helping me with fieldwork and dr. Jan Materna from the The Krkonoše Mountains National Park for your help and service.

\section{References}

BDS - British Dragonfly Society (2012): British Dragonfly monitoring Scheme. <http://british-dragonflies.org.uk/>. Downloaded on 25 July 2012

Cardoso P. (2012): Habitats Directive species lists: urgent need of revision. - Insect Conserv. Diver 5: 169-174.

Clausnitzer V. (2009): Aeshna caerulea. In: IUCN 2012. IUCN Red List of Threatened Species. Version 2012.2. <www.iucnredlist.org>. Downloaded on 24 May 2013.

Dolný A., Bárta D., Waldhauser M., Holuša O. \& Hanel L. (2007): Vážky České republiky: Ekologie, ochrana a rozšíření/ The Dragonflies of the Czech Republic. Ecology, Conservation and Distribution, Český svaz ochránců, Vlašim, 672 pp.

Dolný A. \& Bulánková E. (2004): Odonata of peat bogs of Czech and Slovak Republics. In The sixteenth international symposium of Odonatology. Schwerin, Germany: International Odonatological Foundation (S.I.O.): 19-20.

Flather C.H., Hayward G.D., Beissinger S.R. \& Stephens P.A. (2011): Minimum viable populations: is there a "magic number" for conservation practitioners? - Trends Ecol. Evol. 26: 307-316.

Habel J. C. \& Assmann T. [eds] (2010): Relict Species: Phylogeography and Conservation Biology. SpringerVerlag, Berlin, Heidelberg, $441 \mathrm{pp}$.

Hanel L., Dolný A. \& Zelený J. (2005): Odonata (vážky). p. 125-127. In: Farkač J., Král D. \& Škorpík M. [eds]: Red list of threatened species in the Czech Republic. Invertebrates, Praha: Agentura ochrany přírody a krajiny ČR [2005], 760 pp.

Holuša O. \& Vaněk J. (2008): Fauna vážek (Odonata) Krkonoš. - Opera Corcont. 42: 81-98.

Kalkman V. J., Boudot J.-P., Bernard R., Conze K.-J., De Knijf G., Dyatlova E., Ferreira S., Jović M., Ott J., Riservato E. \& Sahlén G. (2010): European Red List of Dragonflies. Publications Office of the European Union, Luxembourg, vii + 28pp.

Krebs C. J. (1999): Ecological Methodology. Addison-Welsey Educational Publishers, Menlo Park, 620 pp.

Pošta P. (2005): Limnologická studie největšího jezera české části Úpského rašeliniště v Krkonoších. - Opera Corcont. 42: 55-68.

Sternberg K. (1997): Adaptation of Aeshna caerulea (Ström) to the severe climate of its environment (Anisoptera: Aeshnidae). - Odonatologica 26: 439-449.

Traill L.W., Bradshaw J.A. \& Brook B.W. (2007): Minimum viable population size: Ameta-analysis of 30 years of published estimates. - Biol. Conserv. 139: 159-166.

van Tol J. (2005): Global Species Database Odonata. [http://www.odonata.info (25 April 2011) (also available via www.species2000.org)].

Wildermuth H. (2012): Aeshna caerulea in den Schweizer Alpen (Odonata: Aeshnidae). - Libellula Suppl. 12: 77-106.

Author's address: Aleš Dolný, Department of Biology and Ecology/Institute of Environmental Technologies, Faculty of Science, University of Ostrava, Chittussiho 10, CZ-710 00 Ostrava.

E-mail: ales.dolny@ osu.cz 